\title{
Islamic Musical (Nasyid) Production on YouTube: The Relationship between Da'wah Value and Life Skill Education
}

\author{
Ahmad Habibi Syahid ${ }^{1}$, Anita $^{2}$ Sholahuddin Al Ayubi ${ }^{3}$, Hatta Raharja ${ }^{4}$, Azkia Muharom \\ Albantani ${ }^{5}$ \\ \{ahmad.habibi@uinbanten.ac.id ${ }^{1}$, anita.ftk@uinbanten.ac.id², sholahuddin.alayubi@uinbanten.ac.id ${ }^{3}$, \\ hatta.raharja@uinbanten.ac.id ${ }^{4}$, azki@uinjkt.ac.id ${ }^{5}$ \} \\ Universitas Islam Negeri Sultan Maulana Hasanuddin Banten, Jl. Jenderal Sudirman No. 30, Serang ${ }^{1,2,3,4}$ \\ Universitas Islam Negeri Syarif Hidayatullah Jakarta, J1. Ir. H. Djuanda No. 95, Ciputat ${ }^{5}$
}

\begin{abstract}
Da'wah is synonymous with the nuances of mosques and majlis. Da'wah is synonymous with lecturing or giving speeches or recitals at majlis. The reality is that da'wah like this, it cannot be felt by audiences, especially among teenagers. Along with the increasingly dynamic social transformation. Da'wah must be able to answer more realistic problems of the Ummah such as technological developments, media, humanism, welfare, justice, equal rights, and tolerance. In this context, $D a^{\prime}$ wah through the art of music found its momentum. Music that is loved by many people, especially teenagers, and it can attract attention and be an alternative in conveying the mission of $D a^{\prime} w a h$. Music as a medium for $D a^{\prime}$ wah is still considered as seasonal music which only appears at certain times. Nasyid music that is used as a medium for Da'wah is only considered as a complete spice in the world rhetoric of Da'wah. Nasyid music should be of more value than propaganda activities. Because Nasyid not only sings but also preaches. This study discusses critically da'wah through the art of music and religious music production in this case Nasyid music and and how this production is carried out to improve life skill education as a challenge in the era of technological progress. The conceptual of methodology in this study is the preparation (preproduction), manufacturing (production), and marketing (post-production) stages in producing Nasyid music on YouTube. While this research is a case study on the production of YouTube content in the form of Nasyid music and video clips by Nasyid practitioners in Serang. Delivering the right thing is the main goal of every $D a^{\prime}$ 'wah activity. No exception for $D a{ }^{\prime} i$ with music media. Music becomes a fresh morning air of the $D a^{\prime}$ wah world which can attract the audience as a method/media.
\end{abstract}

Keywords: Islamic Musical, Music Production, Relationship, Da'wah, Life Skill Education

\section{Introduction}

Music is a provision that has been giving by Allah SWT since man was born. An example is a sound of a baby crying. Baby cries always emit melodious tones pervading the heart. Everything is sung with a sense of heart through careful tone control. This goes far beyond the meticulousness of a "metal" singer who used to sing in high pitches. [1]

The cry of a newborn baby also implies the meaning that every human being born is not only inspired by musical talent but also has the talent of $d a^{\prime} w a h$. 
Baby's cry is a symbol of communication that can move the conscience of the listener. The language of the baby's day is the power of $d a^{\prime}$ wah that reminds the listener to immediately do good. Milk that can ease his crying is a symbol of the Divine language that we should always consider healthy and quality actions so that one day we can become better human beings. [1] Music and $D a^{\prime}$ wah are human instincts since they were born. Like the example above between the crying baby which is music and breast milk which is a symbol of a da'wah. Therefore it is fortunate for those who can do that when he is an adult.

Music and $d a^{\prime} w a h$ culture is not a new problem in Indonesia. Even more fascinating, the spreaders of Islam in Indonesia, the art of music is seen as important as the da'wah itself.

Therefore, $D a^{\prime}$ wah with the arts including the art of music is a very urgent need at this time, because of $D a^{\prime}$ wah with music as well as meaningful media as amar ma'ruf nahyi munkar. This is also to build the ability of the people's intuition. If $D a^{\prime}$ wah with music is getting more and more popular, the benefits will not only be limited to amar ma'ruf nahyi munkar, but also as an activity of feeling or heart, good for $\mathrm{Da}^{\prime} i$ and Mad'u. The activity of the heart will later produce sensitivity and quality of conscience. [1]

In the development of the media industry, music production is used by musicians including Munsyid to deliver messages ( $\left.D a^{\prime} w a h\right)$ contained in lyric poetry (songs). Nasyid music [2] production is not only seen in terms of entertainment and vocal processing skills, but there is also the value of Da'wah which is carried as the main tool in producing Nasyid music. [3] Nasyid music practionist (Munsyid) will be different from music practionist in general. There is the value of the da'wah brought by Munsyid in creating every lyric and producing it into a song.

Andi Faisal Bakti explained that $D a^{\prime}$ wah is trying to invite people to jointly build this world with full peace (Salam), justice, love, love, ethics and noble morals, to achieve a civilized society that respects each other. [4] If observed the production of Nasyid Banten music aims to uphold Da'wah through Nasyid music it reflects the principles of Da'wah. The production of Nasyid music on YouTube Channel is not only considered as good and beautiful as the songs produced by Munsyid's voices, but there are moral values that are brought as agents who preach the teachings of Islam. it is not only as a value of entertainment and Da'wah but also as a value of life skill education.

The potential of the Nasyid teams in Banten tends to increase. However, with the increasing number of Nasyid teams, they were not guided by the quality of Nasyid music production. Nasyid teams tend to only join in schools without the continuity that leads to life skill education.

The development of music in urban areas through YouTube is becoming a daily consumption. This can be seen from the emerging content creators who came from Banten. The rapid development of technology is the main reason that makes music develop rapidly. Even the mixture of foreign music culture with local music cannot be dammed. This is a challenge as well as a threat especially for Da'wah activists through the production of Nasyid in attracting Mad'u to consume Islamic content.

In general, the interaction between Islam and foreign and local culture in Indonesia can be explained as an arena of contestation, especially between religious and cultural forces, where competing parties use Islamic symbols in interacting with the public. Although it seems like a manipulative practice, the use of Islamic symbols is considered important by the community, especially in Banten, because in general, the Bantenese identify themselves strongly with Islam. Different segments of society respond to these forms of interaction in different ways.

Seeing the above phenomenon, this study aims to explore and explain the relationship between Da'wah and life skill education represented by Munsyid in Banten in Nasyid music 
production on YouTube in the perspective of production institutions with case studies on YouTube content creators in Serang City.

\section{Research method}

This research is a study using virtual ethnographic [5] [6] methods [7] or also called Netnography. [8] To be able to provide the understanding and help discover the dynamics of the relationship between people's culture and cyberspace. [8] This method is also used to explore events that occur about people's behaviour in using the internet to meet certain objectives. [9]

Field research includes a pre-emptive survey which aims to explore phenomena in the community in utilizing technology, interviews, and documentation. This will be done at YouTube content activists in Serang City. The target is YouTube content activists from the Munsyid community who uploaded it to the YouTube channel in Serang City. Besides, this research also includes observations, interviews, and documentation to the parties involved in accommodating the creativity of content activists in Serang City.

\section{Result and discussion}

In this chapter, researchers examine and analyze the relationship between Da'wah and life skill education in producing Nasyid music on YouTube. The researcher begins with a discussion on Islamic musical arts in Banten in this case Nasyid. The discussion focused on people's perceptions of Nasyid music as Da'wah media. After that, researchers examined the production of Nasyid music as a skill and ability in life.

Barendregt said in his research on "Cyber-Nasyid: Transnational soundscapes in Muslim Southeast Asia" that Nasyid's music must be understood with two backgrounds, namely parallel and series processes. He also said earlier that one of the most significant developments in Southeast Asia today is the rise of the Indonesian Muslim-Malay middle class. According to him, Nasyid's music was able to answer the challenges of being a modern Muslim youth in Southeast Asia. [10] and this is the reason for me to research this.

\subsection{Islamic musical arts in Banten}

Islamic musical art that developed in Banten, basically the same as the development in Indonesia. The terminology of Islamic musical art in Banten refers to the art of Islamic music in Indonesia. Like Shalawatan, Qasidah, Marawis, and etc.

Rasmussen in his article entitled "Performing Religious Politics: Islamic Musical Arts in Indonesia" explains that the music discourse is divided into three parts. One of the parts is explaining about Sholawat and Qasida. [2] He added that what Sholawat meant was praise songs for the prophet Muhammad and Qasida is a catchall term for religious song. [2]

Sholawat is a common practice in almost all rituals, and formal groups practice and do religious texts in Arabic often accompanied by drum frames or various combinations of Arabic, Indonesian and Western languages. musical instruments. For example, all of the eight Pondok Pesantren in which I have spent time supporting Qasida Rebana group where singers (girls, boys, or mixed groups) accompany themselves on tambourine drum frames that are 
specific to the Indonesian archipelago. Tambourine rhythm, characterized by strict, interrelated patterns performed by anyone from three to twenty players, has been mistaken by observers as a derivative of Arabic practice, perhaps due to the similarity of Rebana in shape (but not in material) to the drum frames found in throughout the Middle East (such as daf, bendir, tar, riqq, and Mazhar) and, of course, to pair Rebana with Arabic songs. However, the instruments and their various ways are played entirely originating from Indonesia. Rebana ensembles are widespread because they learn to sing religious Sholawat and qasida and play Rebana frame drums in organized groups is a social activity that is common in rural and urban Indonesia, especially for women, teenagers, and children. Sholawat and qasida/qasida Rebana consist of the second musical dialect of Islamic music in Indonesia. [2]

Similarly, the art of religious music (nasyid). The arts of Nasyid have emerged since the mid-1980s into Indonesia. Although that time nasyid is a new entertainment and only developed in high schools and universities. But Nasyid became an icon for intellectuals and slowly expanded beyond campus.

It's nothing new if Nasyid gets the nickname "Kolakan" or "Ramadan music" because Nasyid at the beginning of its appearance does appear only during the fasting month. Even today Nasyid is synonymous with fasting music. While the months other than fasting month Nasyid is rarely heard.

In the late 1990s, especially at the beginning of the monetary crisis in Indonesia, the growth of Nasyid art such as mushrooms in the rainy season came. This type of art in the form of singing together to sing a variety of songs nuanced religious. Seen from the point of time of its population in Indonesia, Nasyid art is a generation that came after the era of Qasidah, Gambus, and others which belong to religious music.

During its development, the Nasyid group used the character of the Nasyid acapella, the Snada Nasyid group. The Nasyid Snada Group is

Indonesia's answer to Malaysia's Nasyid is the Raihan Nasyid group. The breath of the Nasyid Snada group is on campuses or campus life. From there it began to flourish the growth of Nasyid in Indonesia with a variety of musical colors such as instrumental, percussion, acapella and others. Including these developments reaching the Banten area.

Nasyid Nusantara Association, here in after referred to as ANN, is an organization that is a forum for Munsyid, Nasyid activists, Nasyid producers, Nasyid distributors, Nasyid lovers, institutions, institutions, and mass media as well as the general public who want to support Nasyid.

ANN was motivated by the desire of a group of people from various nasyid elements who later called themselves the preparatory committee for ANN's declaration to put nasyid as an art in Indonesia and a crisis of nasyid's existence. With at least nasheed surfacing so nasyid still doesn't have a good place in Indonesian music. ANN has a purpose. The general objective of establishing ANN is to unite the potential of Nasyid in the country.

The Nasyid Nusantara Association (ANN) Banten Province is an association of nasyid activists' associations in Banten province. ANN Banten hereinafter referred to as standing on June 6, 2010, which is centered in the city of Serang. ANN Banten is declared in the AtsTsauroh Great Mosque in Serang City. The first elected chairman by acclamation was Mulyadi who was also a member of the al-Ikhwan Lebak nasyid team. As for the vision and mission of ANN Banten, it still maintains the vision and mission of the ANN Center.

One of the developments in Nasyid music in Banten is the planned production of Banten nasyid music compilation, which is the project of several nasyid teams that are part of ANN Banten. Among the nasyid and soloist teams incorporated in this project are the Syasy nasyid 
team, Vorteza, Syidan, Shavana, the Laz Harfa nasyid team. While the soloists who joined were Kang Imam, and Kang Aris.

Banten nasyid music compilation aims to reintroduce the existence of nasyid among students, especially in the province of Banten. Nasyid is still a magnet at certain events both at schools and at other public events. Especially the nasyid acapella genre becomes its attraction by only relying on the harmonization of the voices of each member of the nasyid team.

\subsection{Nasyid music production on production organization perspective}

According to Uphoff, the terms institutional and organizational are often confusing and interchangeably. Scientifically, social institutions and social organizations are on the same level, to refer to what we are familiar with social groups, groups, social forms, and others that are relatively similar. However, in recent developments, the term "institutional" is more often used for meanings that encompass both. There are several reasons why people prefer the term. Institutionalization is preferred because the word "organization" refers to a social form that is formal, and lately increasingly tends to get a negative image. The word institutional is also preferred because it gives the impression of being more "social" and more respectful of local culture, or more humanistic. [11]

The concept of "production institutions" focuses on the discussion of organization and the tasks of production media management. This concept will be used to understand the process of producing creation and approach to creating self-reliant production with confidence. They also explained this concept in more detail about the stages of producing creation. [12]

The researcher explains the steps in producing a creation that was divided into three steps below

\subsubsection{Pre-production}

To create a superior product, of course, the pre-production stage is required. It is intended that the plan to be carried out in making a product is tested in advance at the pre-production stage. Branston and Stafford divided the pre-production stage into three sub-sections, including research, observation, and design. [12] At this stage, everything is about preparation production tested.

Research is usually done when a proposal has been submitted and has been approved for possible purposes. But in terms of producing something, research is a part that lies in the preproduction stage. Research is carried out at the time the proposal will be made it before the proposal is approved. In general, research is the most important part of the pre-production stage. Because research is like an important part of the academy of media workers. [12] At this stage, Munsyid usually researches in advance in determining what music content on YouTube is interesting to hear. It aims to see the extent to which the content to be produced received good reception from YouTube viewers. So that the content prepared is not only $D a^{\prime}$ wah but also pays attention to packaging and markets as $D a^{\prime}$ wah media.

Good preparation is very basic. That matter aims to the effectiveness of media production. Because at the time before the production of an audio, video, or photo will be made an observation. [12] The things that need to be considered when preparing observations are checking all matters related to the course of production activities. This includes ease of access for people related to production, their health, and in safe conditions. Adequate facilities for a production to take places, such as break rooms, pressure rooms, and public relations rooms. 
[12] This step is done to prepare content that is worth listening to so that many Mad'u are interested in listening.

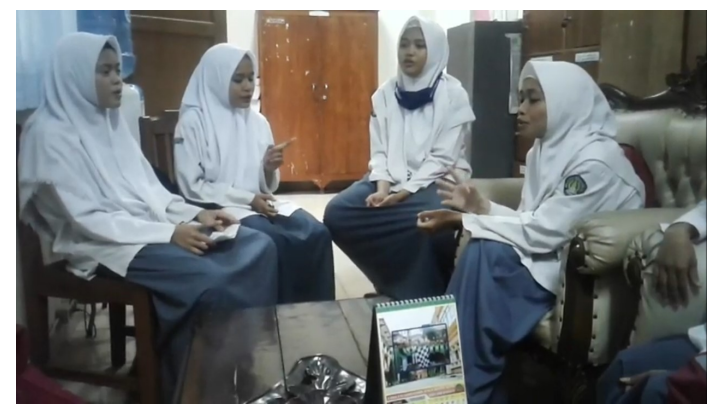

Fig. 1. Nasyid San Guzel preparation before performance (picture screenshotted from https://youtu.be.com/Yjlsu8QYQR0).

Branston and Stafford revealed that "Every media product is" designed ". Each media product certainly requires a design or makes a media product must first be designed. The purpose of the design is to differentiate new products from other media products that are already finished. The design is the first step towards the production stage. Design is needed as initial information for other aspects of production as well as developing initial ideas to develop into larger ideas about a product. [12] As Branston and Stafford said that everything is designed. and the Munsyid produced content also by doing the design.

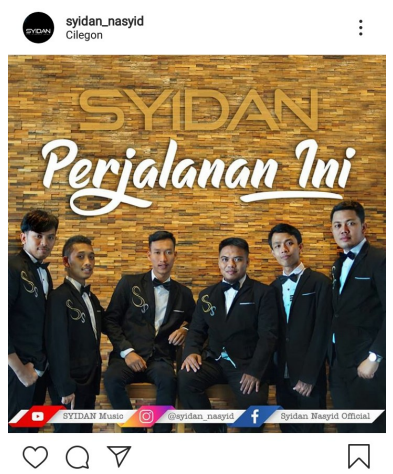

Fig. 2. Latest single cover design from Nasyid Syidan (picture was taken from https://instagram.com/syidan_nasyid).

\subsubsection{Production}

At the manufacturing stage, Branston and Stafford explained that this stage was to explain who was doing what and how the role of the production team (production units) was. [12] At this stage, it is divided into two parts and each part there are sub-units, namely units in 
production consisting of producers, directors or editors, researchers, creative teams, engineering teams, freelances, administrative teams, and presenters. [12]

In producing music Nasyid is the same as producing other music genres. There are stages of production that involve technology. One of them is the recording studio. Musicians, both individuals, and groups, including the group of Nasyid, The recording is a stage to produce audio results that are worth listening to, then mixed with video. This stage also requires technology such as software for video editing. It is intended that the audio files that have been obtained can be synchronized with video files. To produce a product that is suitable for publication on YouTube.

At this stage of production, it is usually more time consuming that is quite long and serious. This is caused by several misses when producing an ingredient or content. If at this stage it is left or not done as well as possible, the finishing or post-production process may experience difficulties.

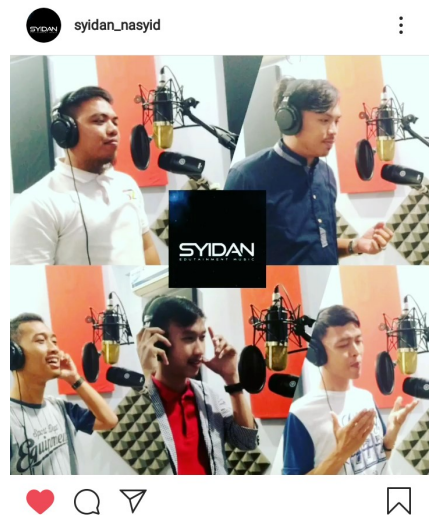

Fig. 3. Recording process in music studio (picture was taken from https://instagram.com/syidan_nasyid).

The recording process should not be done haphazardly because such an attitude will only give birth to vanity. Many Munsyid who have done the recording, but not handled properly finally did not get any beneficial effects from the recording program. Therefore the recording process must be taken seriously. Da'wah through music production will look good when the recording process is done in a serious and not careless way.

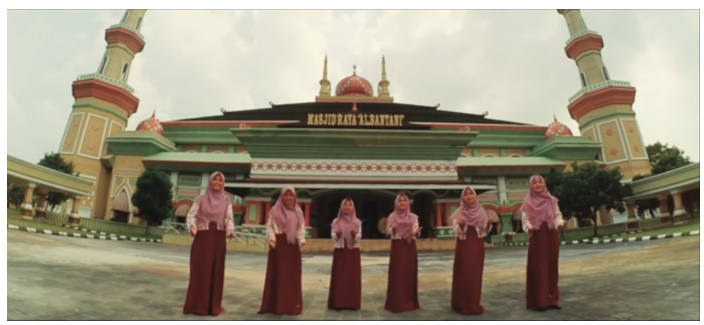

Fig. 4. One of nasyid San Guzel's video clips (picture was screenshotted from https://youtu.be.com/YSW3UWCUv98). 


\subsubsection{Post-production}

A product that has finished being produced does not necessarily end just like that. There is a final stage that becomes final whether the product is suitable for sale in the market or not. That stage is post-production. After a product is finished being produced, the next step is rewriting and editing. This stage can be called the initial evaluation stage before later the product will be distributed and traded. This stage consists of several parts including rewriting, editing, copy-editing, proofing, test marketing (previewing), finishing, distribution, exhibition, audience feedback, and debriefing.

After the recording process is complete and has become religious-themed music. Then the next step is promotion. This is done as a form of da'wah to convey the contents of da'wah contained in poems that have been recorded. Creating a promotional ad as the initial stage of selling a product to be sold. This is usually done by many musicians who have made the process of recording songs that are made including Nasyid groups.

At this stage, Munsyid with various technological conveniences can enable self-production or refer to as indie recording. Especially with the presence of YouTube as a place to channel musical expression without having large budgeting.

\subsection{Nasyid music production on YouTube and life skill education}

Being a Munsyid (da'wah with music) is not only limited to being a musician, but also as a preacher. Or maybe reversed, being a Munsyid not only becomes a Da'i but also becomes a musician.

A Munsyid is not enough to only have musical talent but also needs to have a good attitude. Not only a good attitude on stage but also under the stage or what is meant is in everyday life.

Professional Munsyid is a public figure who will not only be a spectator when he performs on stage. He will become a model when he is in the midst of society. This is because Munsyid is not only a musician but also a da'wah interpreter.

Being a professional musician or singer is not as easy as turning the palm. The success achieved by Melly Goeslaw, Rossa and the stars others is the result of very long efforts. After all, hard effort is a very important process. The long process, of course, must be accompanied by primary efforts such as praying, learning and practicing, having relationships, as well as testing and staging as well as in various competitive events.

The objective conditions of Nasyid art today are very encouraging. Nasyid is no longer popular music but has become folk music. At the age of 15 years, it can be called extraordinary if the reality of the Nasyid then becomes what it is today. Nasyid when this is no longer a musical model dominated by Santri in higher education, but also among school children, fathers, and mothers, including those loved exclusively.

The phenomenon of Nasyid growth reminds us of the phenomenon of a popular song which had been very symptomatic in urban Indonesia in the mid-70s to early $80 \mathrm{~s}$.

One that supports the opportunity to become folk music, considering that Nasyid does not need capital. By only gathering four-five people singing song it is very possible to form a Nasyid acapella or without musical accompaniment. 


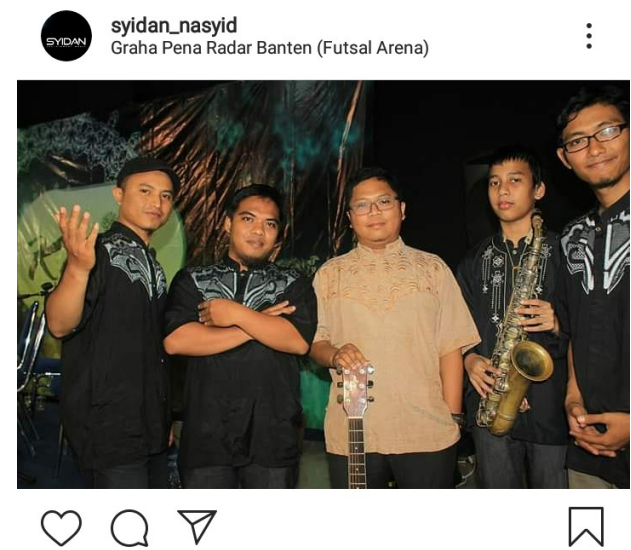

Fig. 5. Filling the program in Islamic Studies on Baraya TV (picture was taken from https://instagram.com/syidan_nasyid).

Another supporting factor that can facilitate the birth of many successful Nasyid artists such as Snada is that Nasyid society never limits the age of new migrant workers. Unlike in pop singer institutions where the age of successful newcomer pop singers must be at least twenty years old.

Snada's existence is enough to show that age is not a very important issue to be a successful murshid. It means about opportunity

Fighting for a new Nasyid group is a separate opportunity for those who want to be consistently successful Munsyids. This is a factor in Banten's desire to make Nasyid-themed content on the YouTube Channel.

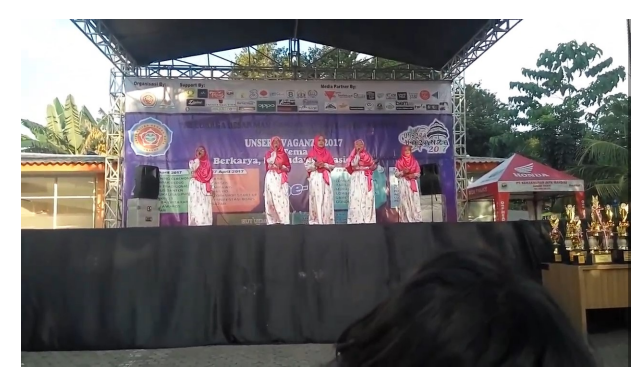

Fig. 4. One of nasyid San Guzel's video (picture was screenshotted from https://youtu.be.com/x4xDE9O3gHI).

Behind the opportunity earlier Munsyid had to struggle to be able to make a quality music product. Surely this must be following what was explained by Branston and Stafford about the theory of production. The existence of production units that have capabilities and stages as a goal of systematic production steps. 


\section{Conclusions}

Delivering the right thing is the main goal of every da'wah activity. No exception for activists da'wah with music media. Music becomes a breath of fresh air for the world of da'wah that can attract you as a method/media.

Da'wah activities through music media certainly must be balanced with the availability of recording facilities to produce verse verses that contain da'wah values. These facilities certainly go into the stages of producing something.

The challenge for creator content, especially from Munsyid. Not only on the number of viewers or subscribers who are increasing, but the positive impact felt by all groups of YouTube content in the form of Nasyid songs. This is the basis that Nasyid is not only intended to preach but also as life skills education. In response to the challenges of the technology era 4.0

\section{References}

[1] A. E. Poetra, Revolusi nasyid. MQS Pub., 2004.

[2] A. K. Rasmussen, "Performing Religious Politics: Islamic Musical Arts in Indonesia," in Music and Conflict, J. M. O’Connell and S. E.-S. Castelo-Branco, Eds. University of Illinois Press, 2010, pp. 155-174.

[3] E. Satria and R. Mohamed, "ANALISIS TERHADAP PERANAN NASYID DALAM DAKWAH,” Jurnal Ilmiah Islam Futura, vol. 16, no. 2, pp. 227-242, Jul. 2017.

[4] "DAKWAH DALAM KOMUNIKASI. 1. Apa definisi dakwah yang komprehensif dan aktual menurut Anda? - PDF." [Online]. Available: https://docplayer.info/230192-Dakwah-dalamkomunikasi-1-apa-definisi-dakwah-yang-komprehensif-dan-aktual-menurut-anda.html. [Accessed: 14-Aug-2019].

[5] L. Nguyen, L. Torlina, K. Peszynski, and B. Corbitt, "Power relations in virtual communities: An ethnographic study," Electron Commerce Res, vol. 6, no. 1, pp. 21-37, Jan. 2006.

[6] C. Hine, "Virtual Ethnography: Modes, Varieties, Affordances," in The SAGE Handbook of Online Research Methods, N. G. Fielding, R. M. Lee, and G. Blank, Eds. SAGE, 2008, pp. 257270.

[7] P. Maclaran and M. Catterall, "Researching the social Web: marketing information from virtual communities," Mrkting Intelligence \& Plan, vol. 20, no. 6, pp. 319-326, Nov. 2002.

[8] Z. Achmad and R. Ida, "Etnografi Virtual sebagai Teknik Pengumpulan Data dan Metode Penelitian," The Journal of Society \& Media, vol. 2, p. 130, Oct. 2018.

[9] L. Sade-Beck, "Internet Ethnography: Online and Offline," International Journal of Qualitative Methods, vol. 3, no. 2, pp. 45-51, Jun. 2004.

[10] B. Barendregt, "Cyber-nasyid: transnational soundscapes in Muslim Southeast Asia," Medi@ asia: Communication, Culture, Context. London: Routledge, 2006.

[11] R. W. Ryan, "Local institutional development: An analytical sourcebook with cases Norman Uphoff for the Rural Development Committee, Cornell University Kumarian Press W. Hartford, Connecticut, 1986, 421 pp.," Public Administration and Development, vol. 9, no. 2, pp. 239-240, 1989.

[12] G. Branston and R. Stafford, The Media Student's Book: Third Edition, 3 edition. London New York: Routledge, 2003. 